\title{
Impact of Intestinal Parasites on Microbiota and Metagenomic Influences on Gene Encoding Cobalamin Pathway
}

Rojelio Mejia ( $\sim$ rmejia@bcm.edu )

Baylor College of Medicine https://orcid.org/0000-0003-4134-4558

Ashish Damania

Baylor College of Medicine

Rebecca Jeun

Baylor College of Medicine

Patricia Bryan

Baylor College of Medicine

Paola Vargas

Universidad Nacional de Salta

Marisa Juarez

Universidad Nacional de Salta

Pamela Cajal

Universidad Nacional de Salta

Julio Nasser

Universidad Nacional de Salta

Alejandro Krolewiecki

Universidad Nacional de Salta

Emilie Lefoulon

New England Biolabs Inc

Courtney Long

New England Biolabs Inc

Evan Drake

New England Biolabs Inc

Ruben Ciminio

Universidad Nacional de Salta

Barton Slatko

New England Biolabs Inc 
Keywords: Giardia lamblia, helminths, cobalamin

Posted Date: December 6th, 2019

DOI: https://doi.org/10.21203/rs.2.18337/v1

License: (c) (i) This work is licensed under a Creative Commons Attribution 4.0 International License. Read Full License 


\section{Abstract}

Background: Approximately $30 \%$ of children worldwide are infected with gastrointestinal parasites. Depending on the species, parasites can disrupt intestinal bacterial flora affecting nutritional status. We implemented a multi-parallel quantitative real-time PCR and whole-genome sequencing analysis for bacterial microbiota and Ascaris lumbricoides, Ancylostoma duodenale, Necator americanus,

Strongyloides stercoralis, Trichuris trichiura, Cryptosporidium species, Entamoeba histolytica, and Giardia lamblia. Stool samples were collected from 37 asymptomatic children from rural Argentina. We focused this study on Giardia screening. Separate analyses were done for uninfected, Giardia only, Giardia/helminth coinfections, and helminth only groups.

Results: For Giardia only infected children, DNA sequencing data showed a decrease in microbiota biodiversity compared to those uninfected that correlated with increasing Giardia burden. Clustering was statistically significant using Shannon alpha diversity. A non-significant increase in diversity was observed for helminth only infections with a compensatory decrease in Giardia/helminth coinfections. In Giardia only infections, microbiome taxonomy shifted from Firmicutes towards increasing proportions of Prevotella, with the degree of shift related to the intensity of infection compared to uninfected. An abundance of Prevotella bacteria was decreased in the helminths only group but increased for Giardia/helminth coinfections. Metagenomic analysis of the bacterial microbiota showed that the proportion of non-vitamin B12 producing bacteria (Prevotella) was higher in the Giardia group. Total cobalamin synthesis was decreased in the Giardia-infected only group compared to the control and helminth-infected group.

Conclusion: Our data provide evidence for an effect of parasitic infections allowing permissive growth of anaerobic bacteria such as Prevotella, suggesting an altered capacity of vitamin B12 biosynthesis and potential impact on growth and development in children.

\section{Background}

Gastrointestinal (GI) parasites are estimated to infect more than two billion people throughout the world[1]. Both soil-transmitted helminths (STH) (Ascaris, hookworm, Strongyloides, Trichuris) and protozoa (Giardia, Cryptosporidium, Entamoeba histolytica) are prevalent in resource-limited areas [2, 3]. Symptoms include chronic diarrhea, severe anemia, and can lead to intestinal obstruction. Economically disadvantaged children have recurrent infections leading to growth and cognitive delays due to malnutrition[4]. These children have more difficulties in school and, subsequently, in the job market[4]. The cycle continues when they remain in poverty and have their children[4]. The link between intestinal helminths and malnutrition leading to growth stunting and anemia has been found by others[5-12], and a new Global Burden of Disease Study points to evidence that hookworm is a leading cause of anemia in resource-poor settings[13]. Valuable information from the Global Enteric Multicenter Study (GEMS) also reveals an unexpected global health impact caused by protozoa $[14,15]$. There are few studies attributing giardiasis to growth delays and no published studies showing the impact on the human intestinal 
microbiome using multi-parallel real-time quantitative (qPCR) detect the presence of Giardia and quantitating the burden of infection[16]. To date, most studies examining intestinal parasitism have not been able to study intestinal worms and protozoa simultaneously and to successfully dissect the relative contribution of each of the significant intestinal helminth or protozoan pathogens to specific diseases.

The current state of diagnosing GI parasites uses the subjective method of microscopy. Depending on the parasite, single stool microscopy exam sensitivity ranges from $50-80 \%[17]$. As a result, large numbers of infected children are not being diagnosed and treated.

Gastrointestinal parasites cause intestinal inflammation, malabsorption, and microbiome changes. With advances in Next Generation DNA sequencing, we are now able to determine a broader range of intestinal microbiota. The microbiome is associated with digestion, nutrition, and health, but alterations in biodiversity can increase disease states and induce intestinal inflammation[18]. There is a lack of literature studying the relationship between GI parasites impact on intestinal microbiome[19]. These few studies have discordant results of the impact parasites have on microbiota biodiversity[20,21].

There is increasing evidence that specific GI parasites (Ascaris) may increase the biodiversity of intestinal microbiota[21]. Since the burden of parasitic infection is directly correlated to morbidity and disease, the load may also impact the intestinal microbiota[21]. Our qPCR quantitates the burden of helminths and protozoa, determining the correlation of burden to changes in intestinal microbiota biodiversity.

Alterations in intestinal microbiota alter bacterial metabolisms, such as vitamin B12, reducing the capacity for human use. Unique to only bacteria is the synthesis of vitamin B12 (cobalamin)[22-24]. Vitamin B12 is a crucial coenzyme for humans cannot produce it, and it must be derived exogenously[25].

\section{Results}

\section{Parasite DNA intensity}

Table 1. Metadata of research subjects (Geometric mean, minimum, and maximum) Parasite DNA intensity associated with the intestinal parasite detection by stool qPCR as described by Rubén et al.

\begin{tabular}{|c|c|c|c|c|c|c|c|c|}
\hline $\begin{array}{l}\text { Groups } \\
\text { (number of } \\
\text { subjects) }\end{array}$ & $\begin{array}{c}\text { Age } \\
\text { Range }\end{array}$ & Male & Female & $\begin{array}{l}\text { Giardia DNA } \\
(\mathrm{fg} / \mathrm{\mu l})\end{array}$ & $\begin{array}{c}\text { Ascaris DNA } \\
(\mathrm{fg} / \mathrm{pl})\end{array}$ & $\begin{array}{c}\text { Ancylostoma } \\
\text { DNA } \\
\text { (fg/pl) }\end{array}$ & $\begin{array}{c}\text { Necator } \\
\text { DNA (fg/pl) }\end{array}$ & $\begin{array}{c}\text { Strongyloides } \\
\text { DNA } \\
\text { (fg/pl) }\end{array}$ \\
\hline Control (5) & $\begin{array}{l}4.5(3 \\
\text { to } 6)\end{array}$ & 3 & 2 & 0 & 0 & 0 & 0 & 0 \\
\hline $\begin{array}{c}\text { Giardia } \\
\text { (13) }\end{array}$ & $\begin{array}{l}5.6(4 \\
\text { to } 7)\end{array}$ & 6 & 7 & $\begin{array}{c}1.12 \text { (0.012 to } \\
20657)\end{array}$ & 0 & 0 & 0 & 0 \\
\hline $\begin{array}{c}\text { Giardia } \\
\text { Helminths } \\
\text { (7) }\end{array}$ & $\begin{array}{l}6.8(4 \\
\text { to } 8)\end{array}$ & 4 & 3 & 0 & 1.062 & $\begin{array}{c}164.8(12.95 \text { to } \\
556.4)\end{array}$ & $\begin{array}{c}0.249(0.03 \text { to } \\
12.47)\end{array}$ & $\begin{array}{c}39.59(9.97 \text { to } \\
157.1)\end{array}$ \\
\hline $\begin{array}{l}\text { Helminths } \\
\text { (12) }\end{array}$ & $\begin{array}{l}5.1(3 \\
\text { to } 7)\end{array}$ & 6 & 6 & 0 & $\begin{array}{l}6.82(4.133 \\
\text { to } 9.67)\end{array}$ & $\begin{array}{c}10627.8(2320 \\
\text { to } 59963)\end{array}$ & $\begin{array}{c}2.839(0.119 \\
\text { to } 63.8)\end{array}$ & 0.01357 \\
\hline
\end{tabular}

\section{Diversity of intestinal microbiota}


Giardia $>1 \mathrm{fg} / \mu \mathrm{l}$ group had a significant loss of biodiversity compared to the non-infected children using Shannon alpha diversity (Giardia-infected $>1 \mathrm{fg} / \mu \mathrm{l}$ 2.346; non-infected group 3.253, $\mathrm{p}=0.0317$ ). Giardia $<1 \mathrm{fg} / \mu \mathrm{l}$ (3.253), Giardia/helminth (3.118), helminths (3.407), with differences between helminth-infected and Giardia/helminth groups $(p=0.0018)$. Giardia $>1 \mathrm{fg} / \mu \mathrm{l}$ had more diversity than the helminth only groups. $(p=0.0003)$. Giardia $>1 \mathrm{fg} / \mu$ l showed an increase in diversity to all other groups $(p=0.0017)$ (Figure 1A).

Measuring bacterial diversity in relation to increasing Giardia DNA intensity of burden $(\mathrm{fg} / \mu \mathrm{l})$ showed an inverse correlation of bacterial diversity to Giardia DNA $(\mathrm{fg} / \mu \mathrm{l})($ Spearman $r=-0.5491, \mathrm{p}=0.0244)$ (Figure 1B).

\section{Bacterial overgrowth}

In Giardia infections, microbiome analysis data shows a decrease in biodiversity in the infected parasite group compared to those non-infected, a bias toward increased Prevotella, with the degree of change related to the intensity of infection (Figure 4). Giardia-infected children had significantly higher proportions of the genus Prevotella bacteria directly correlating to above $1 \mathrm{fg} / \mu \mathrm{l}$ Giardia DNA versus No Parasite group $(p=0.037)$. Comparing all the cohorts revealed the helminth-infected group with decreased Prevotella proportions to Giardia-infected $(p=0.024)$, but similar to the control group. Interestingly, the Giardia-helminth infected group negated these differences compared helminth-infected group ( $p=0.019$ ) (Figure 2). Prevotella copri was the major species in each cohort, Giardia (37\%), Helminths (17\%), No Parasites (22\%), Giardia/Helminths (36\%) (data not shown).

All four groups had different bacteria genera as their most abundant microbiota. Giardia infected children, including Giardia/helminth coinfection, had higher Bacteroidales, including Prevotella species (Figure 3).

\section{Metagenomics of Cobalamin Biosynthesis}

Vitamin B12 InterPro identifier IPR002751 biosynthesis CbiM family was used in the analysis. High Giardia infection had fewer quantities of cobalamin DNA sequences than the No Parasite group $(\mathrm{p}=$ 0.002) (Figure 4A). Children with Giardia and Giardia/Ascaris infections have decreased the proportion of vitamin B12 pathway DNA sequences, compared to children with no parasites $(p=0.021)$ (Figure 4B).

\section{Discussion}

The impact of Giardia on diversity was seen in this study using whole-genome sequencing. While diarrhea caused by giardiasis can reduce the brush border layer in small intestinal cells, the subjects in this cohort were all asymptomatic at the time of stool collection. Giardia likely has a more prominent role, since its primary site of infection and replication is in the small intestine. Giardia is known to cause malabsorption, steatorrhea, and diarrhea[27], with preliminary studies finding improvements in vitamin B12 serum levels after treatment for giardiasis[28, 29]. 
Vitamin B12 synthesis primarily occurs in anaerobes, including Bifidobacterium and Lactobacillus species[25, 30-33]. These microorganisms may promote intestinal homeostasis and may protect against inflammatory diseases[34-37]. Vitamin B12 is absorbed in the small intestines[38-40] while the majority of microbiota reside in the colon[38], although, the small intestine is not sterile and does contain a robust microbiota that influences the absorption of vitamins[41-43]. Prevotella is not known to make an overabundance of cobalamin, the shift to higher Prevotella microbiota proportions decreases the types of vitamin B12 producers[22].

Specific bacteria produce vitamin B12, and the children infected with Giardia may be unable to synthesize the required amounts of vitamin B12 for nutritional benefit. While proportions of vitamin B12 synthesis gene sequences are less than $3 \%$ for each group, this is an appropriate amount of vitamin B12 biosynthesis gene sequences, considering the average stool sample had over 500 species of bacteria (and 22,000,000 sequences)[44].

One limitation of this cross-sectional study is the small sample size. However, the results are consistent, and this potential limitation can be viewed in terms of the sheer number, and fidelity of, using enriched microbe DNA for whole gene sequencing, producing billions of reads for analysis.

A significant consideration that is needed is to ascertain what is occurring in these children. Our findings that the higher burden of Giardia, compared to lower levels, is associated with less microbial diversity and increases of Prevotella. Increased Giardia implies that there are more parasites to alter the intestinal microbiome, and thus have a higher impact on bacterial species.

It is unclear whether the parasites are impacting the intestinal microbiota or external factors such as age, diet, or sex differences altering the intestinal microbiota and making the subjects more susceptible to enabling a Giardia infection. Some evidence comes from a mouse model study where the mouse intestinal microbiota (enteroaggregative Escherichia coli), independent of Giardia infection, can promote inflammation [45].

\section{Conclusions}

In this study, we propose a possible link on why Giardia and other parasites may cause growth and developmental delays in infected children. Evidence of Giardia's impact on diversity and available micronutrients is observed with the Giardia/helminth coinfection group, where alterations of the microbiome are seen in the helminth only group.

While the helminth-infected group did not have changes in diversity or decreased cobalamin synthesis genes, a possible explanation is that most of these helminths reside in the colon and do not alter the microenvironments as does Giardia.

We are currently extending these results to additional populations where Giardia and other intestinal parasite infections are high and are performing, confirming the biochemical analysis of the vitamin B12 
pathway products in affected children.

\section{Methods}

This study aimed to determine the impact of intestinal parasites on bacterial microbiota and subsequent cobalamin metagenomics.

\section{Study population}

Samples were selected from a previously published study using qPCR in peri-urban Argentina[26]. Samples were randomized and selected as representatives of four cohorts, (1) a control group with no parasites detected by qPCR, (2) a Giardia only infected group, (3) a helminth, and Giardia coinfection group, and (4) a helminth only infected group. Helminths included in this study were either Ascaris lumbricoides, Ancylostoma duodenale, Necator americanus, and Strongyloides stercoralis (Table 1).

\section{Multi-parallel real-time quantitative PCR}

All stools were collected and immediately stored in ice and sealed in air-tight containers, frozen within three hours, and DNA extracted using MP FastDNA Spin Kits for Soil (MP Biomedicals, Irvine, CA)[26]. This collection method was found to yield adequate microbiome data for study analysis[20]. Samples were processed in Salta, Argentina, using a modified bead-beating process described previously[26, 46]. DNA was processed for qPCR in Houston, Texas, as previously described [26, 46]. The intensity of parasite DNA was calculated using reference plasmids to create a standard curve, as previously reported[26]. Argentina qPCR results were used in this study[26].

\section{Whole-genome sequencing}

DNA sequencing and library construction were performed at New England Biolabs (NEB). To optimize microbiome sequencing, all samples underwent removal of methylated DNA with NEBNext ${ }^{\circledR}$ Microbiome enrichment kits (New England Biolabs, Ipswich, MA). No DNA size selection was done. DNA Library prep was done per manufacturer protocol with $1 \mathrm{gm}$ of sample DNA used and 8 cycles of PCR enrichment (NEBNext Ultra DNA Library Prep Kit for Illumina, Version 5.1, 9/17). Sequencing was performed using an Illumina NextSeq (Illumina, San Diego, CA) with paired or single ends, and 151 base pair reads.

\section{Bioinformatics}

Fastq reads were filtered for quality at a minimum Phred score of 20 (99\% accuracy) and a minimum length of 50 using Cutadapt version 1.8.3[47]. Paired-end reads were interleaved using merge_fastq_reads_with_N_separator. PI perl script included with LMAT software version 1.2.6[48]. Fastq files were converted to fasta files using seqtk software version 1.0 (https://github.com/lh3/seqtk). Fasta files were processed by LMAT for taxonomic classification using LMAT kFull database. LMAT output text files were filtered for LMAT defined confidence score of 1 and minimum reads of 500 using tolineage.py script. Subsequently, output files were combined using merge_metaphlan_tables.py script 
Included with Metaphlan software[49]. Alpha diversity was calculated using the Phyloseq R package. Abundant different Operational Taxonomic Units (OTU) among four groups were identified using the LEfSe algorithm[50]. Metagenomics analysis was performed using Diamond v0.8.4 using blastx mode

with $90 \%$ minimum identity and e-value of $10^{-5}$ against $\mathrm{nr}$ database fasta file[51]. Results from Diamond analysis were exported to Megan version 6 using daa-meganizer program[52]. GenInfo identifier to Interpro identifier mapping within Megan program was used to annotate the vitamin B12 synthesis gene[53]. STAMP software was used for statistical analysis pertaining to taxonomic and metagenomic differences[54]. Microbial attributes were derived from Livermore Metagenomics Analysis Toolkit (LMAT) taxonomic output using Megan program (Figure 5).

\section{Statistics}

qPCR results were recorded for each patient as positive or negative for each parasite and concentration of parasite DNA. All statistics were performed using Prism v. 7.0b (GraphPad, La Jolla, CA). KruskalWallis test was used to compare multiple groups. Spearman rank to correlate parasite concentrations to Shannon alpha diversity. The Shannon alpha diversity is a commonly reported diversity metric that weights the numbers of species by their relative evenness data[55]. All statistical models used $p$ values less than 0.05 as significant.

\section{Abbreviations}

DNA: Deoxyribonucleic Acid

GEMS: Global Enteric Multicenter Study

Gl: Gastrointestinal

LMAT: Livermore Metagenomics Analysis Toolkit

OTU: Operational Taxonomic Unit

qPCR: Multi-parallel Real-time Quantitative Polymerase Chain Reaction

STH: Soil-Transmitted Helminths

\section{Declarations}

\section{Ethics approval and consent to participate}

The internal review boards approved this study of Baylor College of Medicine and Universidad Nacional de Salta Argentina.

Informed written consent was obtained from each participant or a parent/guardian. Anti-parasitic treatment, based on microscopy findings, was provided per standard of care in the region. The majority of 
subjects were of preschool age and did not receive standard mass drug administration of anthelmintics. The bioethics committee approved study design and protocols of Universidad Nacional de Salta, Argentina (UNSa).

\section{Competing interests}

RM receives research funding from Romark Laboratories, LC. This association did not impact this study.

\section{Funding}

Internal funds from New England Biolabs for DNA sequencing. Research funding support for RM was provided by the US Department of Health and Human Services, Health Resources and Services Administration for Baylor College of Medicine Center of Excellence in Health Equity, Training, and Research (Grant No: D34HP31024). Also, the Baylor College of Medicine Junior Faculty Seed Award was used for research supplies. Microsoft Azure Sponsorship provided funding for cloud computing. Funding also provided by the Texas Children's Hospital Center for Vaccine Development and the National School of Tropical Medicine, Baylor College of Medicine.

\section{Authors contributions}

$R M$ and $A D$ were responsible for bioinformatics and statistical analysis. RM, RJ, and PEB performed DNA extraction, qPCR, demethylation, and library preparation. BS, EL ED, and CL were involved in the DNA sequencing sample reactions and preliminary analysis. PV, MJ, PSC, JN, AK, and ROC collected patient samples in Argentina. RM, AD, and BS wrote the manuscript. All authors read and approved the final manuscript.

\section{Acknowledgments}

We wish to thank Don Comb, Rich Roberts, Tom Evans, Andy Gardner, and Tilde Carlow (from NEB) for support of this project and the NEB DNA Sequencing Core (Laurie Mazzola, Danielle Fuchs, Joanna Bybee).

\section{Availability of data and materials}

The datasets used and/or analyzed during the current study are available from the corresponding author on reasonable request.

\section{References}

1. Brooker S, Clements AC, Bundy DA: Global epidemiology, ecology, and control of soil-transmitted helminth infections. Adv Parasitol 2006, 62:221-261.

2. Bethony J, Brooker S, Albonico M, Geiger SM, Loukas A, Diemert D, Hotez PJ: Soil-transmitted helminth infections: ascariasis, trichuriasis, and hookworm. Lancet 2006, 367:1521-1532. 
3. Baldursson S, Karanis P: Waterborne transmission of protozoan parasites: review of worldwide outbreaks - an update 2004-2010. Water Res 2011, 45:6603-6614.

4. Hotez PJ, American Society for Microbiology.: Forgotten people, forgotten diseases : the neglected tropical diseases and their impact on global health and development. 2nd edn. Washington, DC: ASM Press; 2013.

5. Joseph SA, Casapia M, Montresor A, Rahme E, Ward BJ, Marquis GS, Pezo L, Blouin B, Maheu-Giroux M, Gyorkos TW: The Effect of Deworming on Growth in One-Year-Old Children Living in a SoilTransmitted Helminth-Endemic Area of Peru: A Randomized Controlled Trial. PLoS Neg/ Trop Dis 2015, 9:e0004020.

6. Zhou H, Watanabe $\mathrm{C}$, Ohtsuka R: Impacts of dietary intake and helminth infection on diversity in growth among schoolchildren in rural south China: a four-year longitudinal study. Am J Hum Biol 2007, 19:96-106.

7. Thomas M, Woodfield G, Moses C, Amos G: Soil-transmitted helminth infection, skin infection, anaemia, and growth retardation in schoolchildren of Taveuni Island, Fiji. N Z Med J 2005, 118:U1492.

8. Savioli L, Neira M, Albonico M, Beach MJ, Chwaya HM, Crompton DW, Dunne J, Ehrenberg JP, Gyorkos T, Kvalsvig J, et al: Treatment for intestinal helminth infection. Review needed to take account of all relevant evidence, not only effects on growth and cognitive performance. BMJ 2000, 321:1226-1227.

9. Dickson R, Awasthi S, Williamson P, Demellweek C, Garner P: Effects of treatment for intestinal helminth infection on growth and cognitive performance in children: systematic review of randomised trials. BMJ 2000, 320:1697-1701.

10. Hadju V, Stephenson LS, Mohammed HO, Bowman DD, Parker RS: Improvements of growth, appetite, and physical activity in helminth-infected schoolboys 6 months after single dose of albendazole. Asia Pac J Clin Nutr 1998, 7:170-176.

11. Hadju V, Stephenson LS, Abadi K, Mohammed HO, Bowman DD, Parker RS: Improvements in appetite and growth in helminth-infected schoolboys three and seven weeks after a single dose of pyrantel pamoate. Parasitology 1996, 113 ( Pt 5):497-504.

12. Urban JF, Jr., Romanowski RD, Steele NC: Influence of helminth parasite exposure and strategic application of anthelmintics on the development of immunity and growth of swine. J Anim Sci 1989, 67:1668-1677.

13. Kassebaum NJ, Jasrasaria R, Naghavi M, Wulf SK, Johns N, Lozano R, Regan M, Weatherall D, Chou DP, Eisele TP, et al: A systematic analysis of global anemia burden from 1990 to 2010. Blood 2014, 123:615-624.

14. Kotloff KL, Nataro JP, Blackwelder WC, Nasrin D, Farag TH, Panchalingam S, Wu Y, Sow SO, Sur D, Breiman RF, et al: Burden and aetiology of diarrhoeal disease in infants and young children in developing countries (the Global Enteric Multicenter Study, GEMS): a prospective, case-control study. Lancet 2013, 382:209-222. 
15. Ross AG, Cripps AW: Enteropathogens and chronic illness in returning travelers. N Eng/ J Med 2013, 369:784.

16. Donowitz JR, Alam M, Kabir M, Ma JZ, Nazib F, Platts-Mills JA, Bartelt LA, Haque R, Petri WA, Jr.: A Prospective Longitudinal Cohort to Investigate the Effects of Early Life Giardiasis on Growth and All Cause Diarrhea. Clin Infect Dis 2016, 63:792-797.

17. Mosli M, Gregor J, Chande N, Lannigan R: Nonutility of routine testing of stool for ova and parasites in a tertiary care Canadian centre. Can J Microbio/ 2012, 58:653-659.

18. Jaeggi T, Kortman GA, Moretti D, Chassard C, Holding P, Dostal A, Boekhorst J, Timmerman HM, Swinkels DW, Tjalsma $\mathrm{H}$, et al: Iron fortification adversely affects the gut microbiome, increases pathogen abundance and induces intestinal inflammation in Kenyan infants. Gut 2015, 64:731-742.

19. lebba V, Santangelo F, Totino V, Pantanella F, Monsia A, Di Cristanziano V, Di Cave D, Schippa S, Berrilli F, D'Alfonso R: Gut microbiota related to Giardia duodenalis, Entamoeba spp. and Blastocystis hominis infections in humans from Cote d'Ivoire. J Infect Dev Ctries 2016, 10:1035-1041.

20. Cooper P, Walker AW, Reyes J, Chico M, Salter SJ, Vaca M, Parkhill J: Patent human infections with the whipworm, Trichuris trichiura, are not associated with alterations in the faecal microbiota. PLOS One 2013, 8:e76573.

21. Lee SC, Tang MS, Lim YA, Choy SH, Kurtz ZD, Cox LM, Gundra UM, Cho I, Bonneau R, Blaser MJ, et al: Helminth colonization is associated with increased diversity of the gut microbiota. PLoS Neg/ Trop Dis 2014, 8:e2880.

22. Martens JH, Barg H, Warren MJ, Jahn D: Microbial production of vitamin B12. Appl Microbiol Biotechnol 2002, 58:275-285.

23. Roth JR, Lawrence JG, Bobik TA: Cobalamin (coenzyme B12): synthesis and biological significance. Annu Rev Microbio/ 1996, 50:137-181.

24. Lawrence JG, Roth JR: Evolution of coenzyme B12 synthesis among enteric bacteria: evidence for loss and reacquisition of a multigene complex. Genetics 1996, 142:11-24.

25. LeBlanc JG, Milani C, de Giori GS, Sesma F, van Sinderen D, Ventura M: Bacteria as vitamin suppliers to their host: a gut microbiota perspective. Curr Opin Biotechnol 2013, 24:160-168.

26. Cimino RO, Jeun R, Juarez M, Cajal PS, Vargas P, Echazu A, Bryan PE, Nasser J, Krolewiecki A, Mejia $R$ : Identification of human intestinal parasites affecting an asymptomatic peri-urban Argentinian population using multi-parallel quantitative real-time polymerase chain reaction. Parasit Vectors 2015, 8:380.

27. Cain GD, Moore P, Jr., Patterson M: Malabsorption associated with Giardia lamblia infestation. South Med J 1968, 61:532-534.

28. Olivares JL, Fernandez R, Fleta J, Ruiz MY, Clavel A: Vitamin B12 and folic acid in children with intestinal parasitic infection. J Am Coll Nutr 2002, 21:109-113.

29. Ventura LL, Oliveira DR, Viana JC, Santos JF, Caliari MV, Gomes MA: Impact of protein malnutrition on histological parameters of experimentally infected animals with Giardia lamblia. Exp Parasitol 2013, 133:391-395. 
30. Turroni F, Marchesi JR, Foroni E, Gueimonde M, Shanahan F, Margolles A, van Sinderen D, Ventura M: Microbiomic analysis of the bifidobacterial population in the human distal gut. ISME J 2009, 3:745751.

31. Turroni F, Foroni E, Pizzetti P, Giubellini V, Ribbera A, Merusi P, Cagnasso P, Bizzarri B, de'Angelis GL, Shanahan F, et al: Exploring the diversity of the bifidobacterial population in the human intestinal tract. Appl Environ Microbiol 2009, 75:1534-1545.

32. Ventura M, Turroni F, Motherway MO, MacSharry J, van Sinderen D: Host-microbe interactions that facilitate gut colonization by commensal bifidobacteria. Trends Microbiol 2012, 20:467-476.

33. Turroni F, Peano C, Pass DA, Foroni E, Severgnini M, Claesson MJ, Kerr C, Hourihane J, Murray D, Fuligni F, et al: Diversity of bifidobacteria within the infant gut microbiota. PLoS One 2012, 7:e36957.

34. Salminen S, Nybom S, Meriluoto J, Collado MC, Vesterlund S, El-Nezami H: Interaction of probiotics and pathogens-benefits to human health? Curr Opin Biotechno/ 2010, 21:157-167.

35. Lomax AR, Calder PC: Probiotics, immune function, infection and inflammation: a review of the evidence from studies conducted in humans. Curr Pharm Des 2009, 15:1428-1518.

36. Ghouri YA, Richards DM, Rahimi EF, Krill JT, Jelinek KA, DuPont AW: Systematic review of randomized controlled trials of probiotics, prebiotics, and synbiotics in inflammatory bowel disease. Clin Exp Gastroenterol 2014, 7:473-487.

37. Sjoberg F, Barkman C, Nookaew I, Ostman S, Adlerberth I, Saalman R, Wold AE: Low-complexity microbiota in the duodenum of children with newly diagnosed ulcerative colitis. PLOS One 2017, 12:e0186178.

38. Gille D, Schmid A: Vitamin B12 in meat and dairy products. Nutr Rev 2015, 73:106-115.

39. Glass GB, Boyd LJ, Stephanson L: Intestinal absorption of vitamin B12 in man. Science 1954, 120:74-75.

40. Glass GB, Boyd LJ, Stephanson L: Intestinal absorption of vitamin B12 in humans as studies by isotope technic. Proc Soc Exp Biol Med 1954, 86:522-526.

41. Onishi JC, Campbell S, Moreau M, Patel F, Brooks Al, Zhou YX, Haggblom MM, Storch J: Bacterial communities in the small intestine respond differently to those in the caecum and colon in mice fed low- and high-fat diets. Microbiology 2017, 163:1189-1197.

42. Ghoshal UC, Shukla R, Ghoshal U: Small Intestinal Bacterial Overgrowth and Irritable Bowel Syndrome: A Bridge between Functional Organic Dichotomy. Gut Liver 2017, 11:196-208.

43. Ghoshal UC, Ghoshal U: Small Intestinal Bacterial Overgrowth and Other Intestinal Disorders. Gastroenterol Clin North Am 2017, 46:103-120.

44. Saulnier DM, Riehle K, Mistretta TA, Diaz MA, Mandal D, Raza S, Weidler EM, Qin X, Coarfa C, Milosavljevic A, et al: Gastrointestinal microbiome signatures of pediatric patients with irritable bowel syndrome. Gastroenterology 2011, 141:1782-1791.

45. Bartelt LA, Bolick DT, Mayneris-Perxachs J, Kolling GL, Medlock GL, Zaenker El, Donowitz J, ThomasBeckett RV, Rogala A, Carroll IM, et al: Cross-modulation of pathogen-specific pathways enhances 
malnutrition during enteric coinfection with Giardia lamblia and enteroaggregative Escherichia coli. PLoS Pathog 2017, 13:e1006471.

46. Mejia R, Vicuna Y, Broncano N, Sandoval C, Vaca M, Chico M, Cooper PJ, Nutman TB: A novel, multiparallel, real-time polymerase chain reaction approach for eight gastrointestinal parasites provides improved diagnostic capabilities to resource-limited at-risk populations. Am J Trop Med Hyg 2013, 88:1041-1047.

47. Bolger AM, Lohse M, Usadel B: Trimmomatic: a flexible trimmer for Illumina sequence data. Bioinformatics 2014, 30:2114-2120.

48. Ames SK, Hysom DA, Gardner SN, Lloyd GS, Gokhale MB, Allen JE: Scalable metagenomic taxonomy classification using a reference genome database. Bioinformatics 2013, 29:2253-2260.

49. Segata N, Waldron L, Ballarini A, Narasimhan V, Jousson O, Huttenhower C: Metagenomic microbial community profiling using unique clade-specific marker genes. Nat Methods 2012, 9:811-814.

50. Segata N, Izard J, Waldron L, Gevers D, Miropolsky L, Garrett WS, Huttenhower C: Metagenomic biomarker discovery and explanation. Genome Biol 2011, 12:R60.

51. Buchfink B, Xie C, Huson DH: Fast and sensitive protein alignment using DIAMOND. Nat Methods 2015, 12:59-60.

52. Huson DH, Auch AF, Qi J, Schuster SC: MEGAN analysis of metagenomic data. Genome Res 2007, 17:377-386.

53. Mitchell A, Chang HY, Daugherty L, Fraser M, Hunter S, Lopez R, McAnulla C, McMenamin C, Nuka G, Pesseat $S$, et al: The InterPro protein families database: the classification resource after $\mathbf{1 5}$ years. Nucleic Acids Res 2015, 43:D213-221.

54. Parks DH, Beiko RG: Identifying biologically relevant differences between metagenomic communities. Bioinformatics 2010, 26:715-721.

55. Reese AT, Dunn RR: Drivers of Microbiome Biodiversity: A Review of General Rules, Feces, and Ignorance. MBio 2018, 9.

Figures

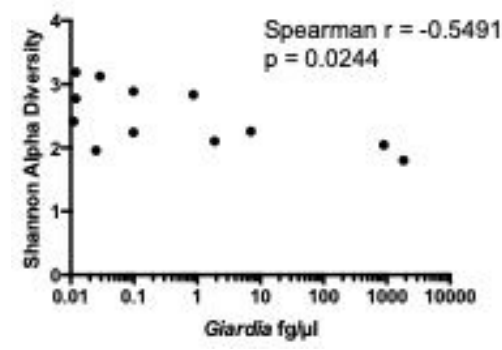

Figure 1

Greater than $1 \mathrm{fg} / \mu \mathrm{l}$ Giardia DNA has a significant decrease in bacterial diversity to the No Parasite group $(p=0.0244)(1 A)$. There was an inverse correlation of higher than $1 \mathrm{fg} / \mu \mathrm{l}$ of Giardia DNA to decreased 
Shannon alpha diversity (Spearman $r=-0.5491, p=0.0244)(1 B)$.
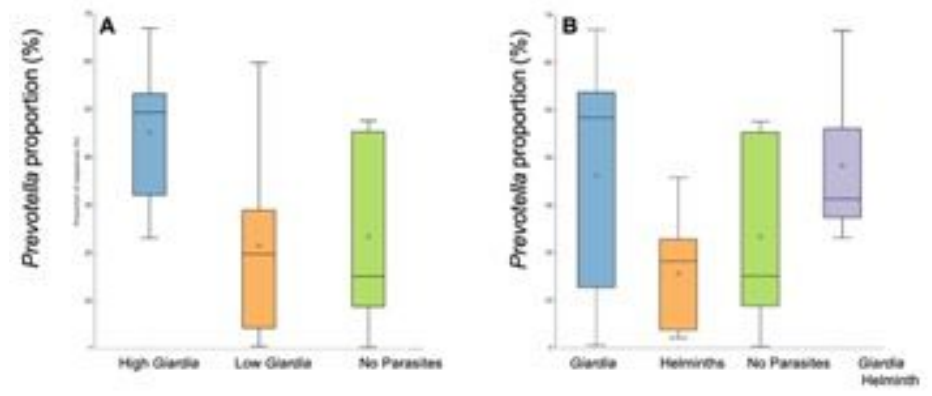

\section{Figure 2}

Giardia $>1 \mathrm{fg} / \mu \mathrm{l}$ group had more abundant Prevotella than No Parasite group $p=0.037(2 \mathrm{~A})$ with Helminths group decrease Prevotella to Giardia group $(p=0.024)$ and Giardia/helminth co-infected negating these differences $(p=0.019)(2 B)$.

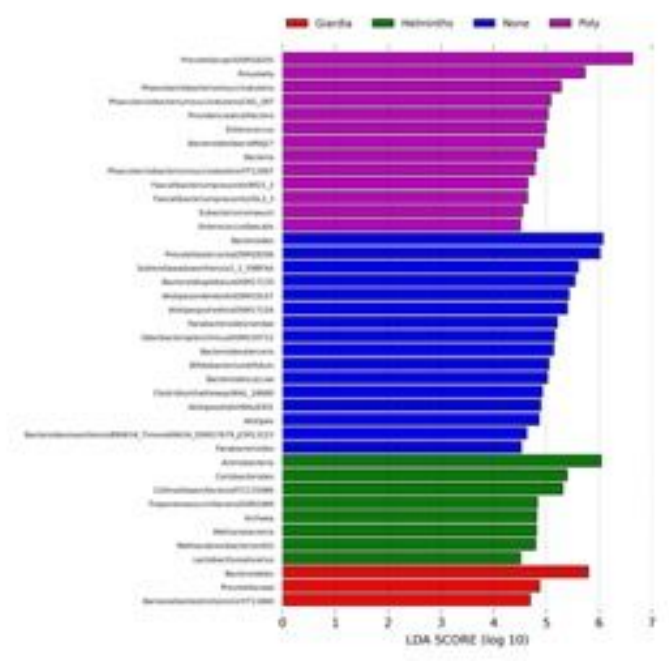

Figure 3

Most abundant OTUs for each cohort using LDA Effect Size (LEfSe)

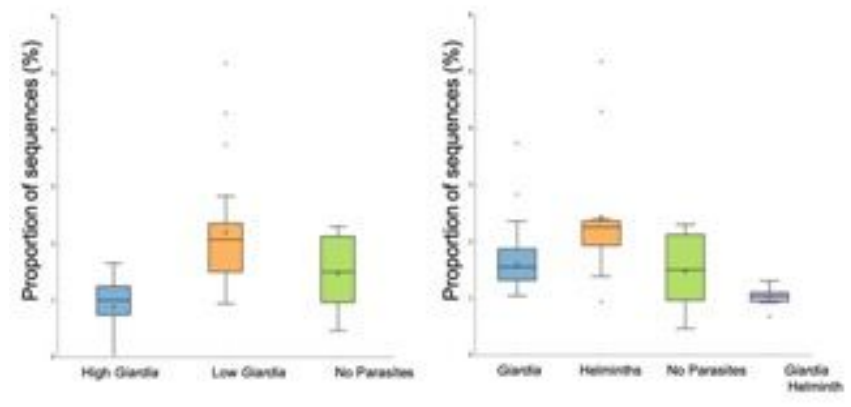

Figure 4

High Giardia infected children had decreased cobalamin biosynthesis genes compared to No Parasites ( $p$ $=0.038)(4 A)$ with compensatory effects from helminth infections $(p=0.021)(4 B)$. 


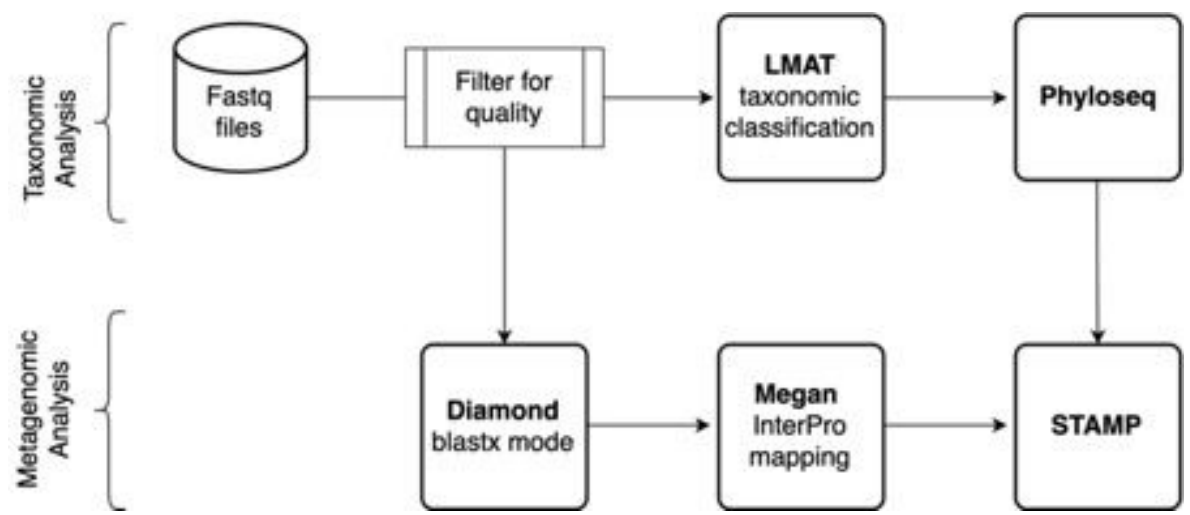

Figure 5

Flow chart for bioinformatics and data processing. 